\title{
Review of Michael Sandel's What money can't buy: the moral limits of markets. New York: Farrar, Straus and Giroux, 2012, 256 pp.
}

\author{
THOMAS R. WELLS \\ Erasmus Institute for Philosophy and Economics
}

Michael Sandel's latest book is not a scholarly work but is clearly intended as a work of public philosophy-a contribution to public rather than academic discourse. The book makes two moves. The first, which takes up most of it, is to demonstrate by means of a great many examples, mostly culled from newspaper stories, that markets and money corrupt-degrade-the goods they are used to allocate. The second follows from the first as Sandel's proposed solution: we as a society should deliberate together about the proper meaning and purpose of various goods, relationships, and activities (such as baseball and education) and how they should be valued.

Public philosophy is a different genre from academic philosophy, but that does not mean that it cannot be held to high standards. In my view, while this book does provide food for thought and food for conversation, it nevertheless has significant failings as a work of public philosophy rather than journalistic social activism on the model of Naomi Klein's No logo (1999).

\section{THE CORRUPTION THESIS}

Before moving to discuss Sandel's corruption thesis, let me sketch the context of the debate. A market is an institutionalised space in which goods and services can be exchanged for reasons of direct self-interest, usually though not necessarily via the medium of money (Herzog 2013). Market exchange may be contrasted with other arrangements for allocating goods, such as those identified by Karl Polanyi (1944, chapter 4): reciprocity between individuals (such as gift exchange systems), redistribution by government, and autarky in which people produce what they need for themselves (such as subsistence farming). Economists like markets because, under certain conditions (such as rivalrous competition between multiple producers) they tend to promote the efficient allocation of resources, as well as innovations that make 
those resources go further. The story of the world's increasing material prosperity over the last few hundred years is the story (Adam Smith's story) of the rise of markets, which have allowed individuals to meet more of their wants and needs than ever before, and, through taxation, have also permitted an enormous expansion in the provision of public services by governments (education, health, security, law, transport infrastructure, and so on). The practical success of the market economy is sometimes taken to imply that, other things being equal, markets are the best way of organising the production and distribution of everything. But are other things equal? The critique of the market comes from three directions.

Economists themselves are the first to point out the limits of markets. They recognise that the conditions for a successful market are actually quite demanding, and that where they are not met, such as in the case of 'natural monopolies' or public goods, alternative institutional arrangements may well perform better. For example, while it is possible to have drinking water supplied by competing fleets of tankers, and this is something one actually finds in cities in poor countries, it is far cheaper to have a single-regulated or publicly owned-water utility company running a pipe network. (This is why drinking water costs less in London than in the slums of Manila, Jakarta, or Nairobi.) Another example is the economic justification for firms themselves (Coase 1937). Although firms obviously buy their inputs and sell their products in markets, their internal organisation is a bureaucratic command economy whose operations are carefully shielded from the market. That is largely because contractual relationships between self-interested strangers often impose high transaction costs that make them uneconomical. Economists thus use the instrumental criterion of efficiency to draw the limits of the market. Markets should only be used where they are more efficient than other arrangements.

In contrast to economists, moral philosophers have tended to focus on the fairness of market arrangements, especially with whether they produce (outcome) inequality or are characterised by (procedural) exploitation. Take inequality first. On the one hand markets generate inequality in wealth as a by-product of the competition that drives them. On the other hand, markets work by discriminating between different people's wants on the basis of their willingness-to-pay, which has an obvious relation to their ability-to-pay. Thus, while markets may 
increase the aggregate productivity of an economy, unless the purchasing power of market losers is somehow restored, such as by government intervention, they may not benefit much if at all from that prosperity.

Exploitation concerns the abuse of power within transactional relationships that undermines their moral legitimacy. Many contemporary economists argue that so long as transactions are voluntary, exploitation is impossible by definition. But that extrapolates too easily from institutional and social context. Individuals (or corporations) can take advantage of inequalities such as of wealth, legal rights, information, or their possession of some extraordinarily valuable good (like a scarce medicine) to 'offer' vulnerable people a choice they cannot refuse. Exploitation is endemic in real world (as opposed to ideal theoretical) capitalism, from sweatshops underpaying illegal immigrants to work in dangerous conditions, to payday loan companies preying on the poor, to pharmaceutical companies' extraordinary pricing of patented medicines to maximise the profits of monopoly rather than lives saved.

Note that exploitation can often be addressed by governments reforming and even deepening market institutions to make their performance better resemble the economist's ideal. For example, by empowering illegal immigrants to assert their equal labour rights; by supporting the development of alternative lending institutions for the poor (such as credit unions); and by introducing alternative incentives for innovation than intellectual property. But simply providing the exploited with more market choices without addressing their powerlessness may not be helpful. For example, allowing vulnerable people to send their children to work, to sell their kidneys, to work longer hours, and so forth, may merely open up new domains of immiseration (Satz 2010).

Sandel's critique is not about efficiency or fairness. Rather, he follows a third tradition in worrying about how the value or meaning of goods themselves is corrupted by going through markets. What is this corruption? Sandel argues that "[t]o corrupt a good or a social practice is to degrade it, to treat it according to a lower mode of valuation than is appropriate to it" (pp. 29-30). According to this hierarchy, scalping free tickets to a papal mass, accepting the children of 'donors' to prestigious universities, selling baseball memorabilia, and so on, 
degrades the nature of what is being sold. Selling such things profanes them.

The central failure of the book is Sandel's disinterest in developing his corruption critique systematically-philosophically. The references are telling. While dozens of economists are mentioned and often discussed in some depth, the philosophers like Michael Walzer (1983), Elizabeth Anderson (1993), and Margaret Radin (1996) most associated with developing this corruption thesis are almost entirely absent (a footnote acknowledges Anderson in general terms). Even Aristotle only receives a couple of lines. Indeed, the domination of economics is really quite astonishing-much of the theoretical level of the book consists of pitting the hack psychology of contemporary behavioural economics against a parody of neoclassical economics (which Sandel confuses with markets which he confuses with money). In contrast, sociology, the academic discipline actually tasked with investigating social meaning, is absent, with the exception of a famous but empirically outdated work by Richard Titmuss (1970). Even a casual glance into the sociological literature shows that the interesting issue is not whether 'the market' is bad for social relationships and morality but the complex dynamics of their interaction, such as how wages confer dignity as well as income, how couples negotiate the economic dimensions of intimate relationships (Zelizer 2009), and so on.

Sandel's economistic theoretical framework is complemented with dozens of (mostly American) newspaper stories of unconventional things being for sale. Sandel's principal rhetorical strategy appears to be to evoke disgust in his readers, at the idea of people being allowed to pay money to avoid queuing; companies buying and trading life insurance on their employees; rich people paying to hunt endangered species; poor people having themselves tattooed with a casino website address; etc. This strategy is distinctly limited.

First, the moral significance of what Sandel calls corruption is poorly explained. His case more or less begins and ends by evoking readers' disgust at the ugliness of the practices he identifies. Yet this seems a primarily aesthetic response-ugliness being a perception of impropriety between form and substance-that has no prima facie connection to moral value. "Yuk!" is not an argument, moral philosophers teach undergraduates in introductory classes. Basing moral appraisals on one's aesthetic response to appearances-the presence of dollar signs-leads to polemical excesses, such as claims 
that education, baseball, kidney transplants, friendship, parenthood, religion, and the like, are spoiled for everyone by the commercial innovations Sandel discusses.

Sandel has a point-transactional arrangements can change meanings and relationships, sometimes for the worse-but his method can only detect transgressions of convention, not their moral valence or significance. What might be called the zoning approach to moral philosophy focuses on whether things are in their rightful place, not whether it matters that they are. This interferes with-perhaps in this context I should say 'crowds out'-the more nuanced and persuasive case that Sandel sometimes tries to make. For example when he turns from explaining how paying children $\$ 2$ to read a book corrupts reading to the worrying domination of the cash incentives paradigm in American education policy circles (pp. 40-43). ${ }^{1}$

Second, it is recent transgressions that catch the eye, and thus the moral opprobrium. This makes Sandel's journalistic critique peculiarly specific to his time and place. He seems to benchmark the acceptable limits of the logic of buying and selling to what he grew up with. Thus he does not see life insurance itself as morally controversial, as it was in the 19th century, only such recent innovations as its use and trade by third parties such as employers. Advertising around baseball stadiums is fine since that was how things were when he was a child, but not on the bases! And so on.

The problem here is that Sandel's moral analysis seems hostage to whatever social norms happened to prevail in his formative years. It turns out that commercial innovations are quickly digested and normalised by society. For example it is now normal and hence morally invisible for politicians to pay professionals to write their speeches. Sandel spends several pages criticising the idea of paying someone to write your wedding toast. But if buying political speeches is fine, can we

\footnotetext{
${ }^{1}$ Indeed, I wish Sandel had developed the point further. Extrinsic motivations-i.e., incentives-have always been used to inculcate self-sustaining habits, as children are taught to eat their vegetables with the promise of desert. But it seems increasingly common for managers exercising bureaucratic power, and politicians responsible for public services, to rely entirely on extrinsic motivations (see Grant 2012). This attitude not only demeans the people under their power. Despite its apparent hard-nosed pragmatism it is also practically foolish, as a moment's consideration of the idea of paying someone to be honest or loyal will show. Sandel is surely mistaken to assert that paying children to read books is morally wrong or corrupting in itself. But if incentives-for teachers as well as students-have become the only or main resort of politicians and civil servants, that reflects a failure of imagination that impoverishes us all.
} 
really justify the general intuition Sandel appeals to, that a bought wedding toast has less value than an 'authentic' one? And can we have any confidence that that intuition will continue to be widely shared in 10 or 20 years?

Money is ubiquitous in a commercial society as the universal currency of remuneration. Activities which are not sufficiently remunerated will generally not be supplied, because it is not sustainable to produce them except as a kind of hobby (the difference between professional baseball and Saturday afternoon amateurs). It is therefore hardly surprising that all sorts of valuable things are supplied in exchange for money. Bibles are published and sold commercially (as is Sandel's book); elected politicians receive salaries; pharmaceutical companies put prices on their life-saving medicines; and so on. Sandel seems to accept all this. But then his criticism of changes to what he grew up thinking of as normal seems arbitrary. Why is it only in these 'new' cases that the appearance of money engenders corruption? Why does advertising inside novels pose a threat of corruption but not advertising inside news media?

Sandel's corruption thesis appears to lack the resources to critically analyse what is socially accepted as normal. If he had been born 30 years later, one can only suppose that he would think the vulgarities of baseball skyboxes and memorabilia markets were normal and right. Sandel's approach thus has a strong conservative orientation-an attachment to and desire to preserve things in their familiar form.

\section{SANDEL'S ILLIBERAL POLITICAL SOLUTION}

Some left-leaning liberals (in the political philosophy sense of liberal) will endorse Sandel's book simply because it criticises markets. They should be careful. Sandel's is really a reactionary social conservative approach, and one that conflicts with many principles that liberals should hold dear. ${ }^{2}$

First, while Sandel dates the commercialisation of society to the 1980s market triumphalism of Ronald Reagan and Margaret Thatcher, he never mentions neo-liberalism, the dominant critical account of this developed on the left. His book attempts a cultural critique of market transgressions that quite deliberately sidesteps that ongoing political

\footnotetext{
${ }^{2}$ I do not mean to assert Sandel's political affiliation with any particular political party. Indeed, variations on his communitarian conception of political society animate, or at least appeal to, many on both the left and right of mainstream politics.
} 
debate about how conflicts between fairness, liberty, and prosperity should be resolved. But merely because Sandel is also a critic of the ideology of markets does not make him an ally of egalitarians, for he implicitly prioritises cultural integrity above concerns about fairness.

Sandel argues that the expansion of transactional arrangements comes at the expense of alternative 'moral' relationships and implies that this is always a bad thing. Yet liberal political philosophers have long noted that traditional social institutions are as capable of gross injustice and inhumanity as market ones, despite having the form of being animated by reciprocal benevolence and respect. In particular, they tend to generate cloying moral obligations that suffocate the individuality, rights and freedoms of lower status members of the community. Meaning is often preserved through oppression and facilitates exploitation.

It follows that the undermining of social ties and traditional values associated with the extension of the transactional economy can actually be worth fighting for, to free people from imprisonment in unchosen and degrading social norms and relationships. For example, the idea that the family should be a domain of love and solidarity protected from the heartless business of the world does not so much negate the scope for despotism within intimate relationships as help render such despotism beyond criticism or resistance (e.g., Sen 1990). Hence the long campaign by feminists for the civil right of women to paid work-the freedom to sell their labour in the market-and Susan B. Anthony's famous slogan "Woman must have a purse of her own".

Second, is the general dangerousness of the amorphous but visceral concept of corruption, which has a long association with intolerant strains of political conservatism, for example, in support of racist politics. The problem is that 'corruption' refers to the category of those transgressions of social norms that trigger a moral disgust reflex and, despite Sandel's claims to the contrary, this is a mode of moralising rather than of critical reflection. For instance, the claim that gay marriage corrupts the traditional institution of marriage works in just the same way as Sandel asks us to think about his examples. The rhetoric of purity and pollution presents a danger not a wonderful opportunity for the liberal conception of democracy, for it is a licence for imposing the private moral beliefs of the powerful or the many over the rights of minorities. 
Sandel's implicit illiberalism should not be surprising-after all, he made his name as a communitarian critic of Rawls's political philosophy. Like 'defenders' of straight marriage, Sandel is anxious to politicise value questions. Contemporary US politics is "empty of moral and spiritual content", because it involves endless argument over things like taxes and spending but "fails to engage with big questions that people care about" (pp. 14-15). In particular, Sandel argues that a community should ask itself the Aristotelian question-what are such activities as education and baseball for?-and thus determine how they should be valued and how they should treated (pp. 153-154). Sandel never really elaborates on this political dimension of his argument. Perhaps because he recognises that few readers would be willing to go all the way along with this illiberal view of politics as a space for determining what thick set of values should animate an entire society, for example whether America is a Christian nation.

The liberal conception of politics is committed to separating the private and public spheres, to secluding a substantial domain of individual life from public scrutiny and collective decision-making. Liberal institutions like markets and secularism help realise this dichotomy by privatising contentious moral issues rather than politicising them. (In an ironic twist on his zoning approach to moral philosophy, here it is exactly the market's role in separating private and public domains that Sandel objects to (pp. 15-16)). From the liberal perspective it simply isn't the business of democratic politics to make decisions about how everyone in society should value baseball, and to ban whatever might corrupt that purpose, such as the trade in memorabilia, moneyball methods of selecting players, or seat-pricing differentiation criticised by Sandel. To the contrary, liberal polities deliberately make space for the endogenous and spontaneous creation of new practises and values from the free interaction of individuals. Liberal democracy is also comfortable with and committed to respecting value pluralism, not least because the burdens of judgement identified by John Rawls lead to persistent disagreements even between reasonable people (Rawls 2005, 54-58). Sandel notes that the 'true purpose' of many of the goods, relationships, and activities he discusses is contested. But he asserts that a community can determine the single right answer to such value questions and that this is what democratic politics is for. 


\section{AGAINST RAPACIOUS CAPITALISM}

Clearly I am not a big fan of Sandel's corruption thesis. Yet his book can also be read in a more general way as a critique of the scale of incursions of commercial practises into our civic and private life. Many of Sandel's examples relate not to the theme of market corruption but to what I call 'rapacious capitalism', which is characterised by the treatment of human beings (and everything else) only as a means, as an object of cold calculation, as a site of potential profit. The cumulative effect of Sandel's myriad examples is to expose the prevalence of this rapaciousness, and to arouse a healthy attitude of critical resistance to it.

Rapacious capitalism is the translation of the all too human drive to dominate and exploit others into the structures and relationships of capitalist society. It has many dimensions, from the political to the environmental. At the political level, for example, we see multinational companies and rich individuals exploiting loopholes in the international tax system to evade regulatory oversight and avoid paying their fair share. Industries like finance and oil \& gas co-opt our democratic institutions to transfer the risks and costs of their business models onto society as a whole. And so on.

Rapacious capitalism inflicts its greatest harms on the vulnerable (such as hourly workers, or livestock animals). Yet even the middle-class readers of Sandel's book know what it is to be relentlessly targeted for commercial exploitation. The internet for example, once idealised as a worldwide democratic commons, has been commercialised so thoroughly that every time we go online our identities are being tracked and hacked to be sold off to third parties, who will use the resulting profiles to target us ever more assiduously. Advertising itself, a dominant motif in Sandel's book, is built on the exploitation of property rights loopholes. It consists of the sale of our attention between third parties without our consent. The intrusion of advertising into more and more spaces in modern life-our clothes, our fruit, eggs, stamps, police cells, toilets, inside novels, poor people's foreheads, and so forthmakes one long for spaces of tranquillity free from its incessant intrusive manipulations (much as Sandel longs for the baseball of his childhood memory). A recent New Yorker short story about a family visit to a theme park portrays the ordinary individual's experience of rapacious capitalism rather well: 
He felt squeezed into grooves of expertly predicted responses and behavior, of expenditures of sweat and hilarity and currency from his wallet and also his soul. He was as helpless as a pinball coursing in a table-top machine... It struck him now that the park's design was somehow alimentary. You were being engulfed, digested, shit out (Lethem 2014, 59-60).

This rapacious capitalism is what unites the moral philosopher's critique of the exploitative dimensions of capitalism with Sandel's concerns about the degrading effects of commercial incursions into our private and civic life. It is why such apparent trivialities as adverts appearing on grocery store fruit and eggs should be classed together with the systemic targeting of children by merchandisers and advertisers, in and out of school. (Sandel notes that advertising to children in America has increased more than 150 fold since the early 1980s.)

Rapacious capitalism is not a new problem. The corollary of the tendency to gentle manners produced by mutually beneficial trade (the providential doux commerce thesis promoted by Hume, Smith, and Montesquieu) is the tendency to hyper-aggressiveness produced by competitive rivalry between economic players for that trade. As in warfare, such hyper-aggression corrupts our sense of morality and wreaks devastation upon societies and individual lives. Yet it is not inevitable. As Adam Smith put it in the Wealth of nations,

The violence and injustice of the rulers of mankind is an ancient evil, for which, I am afraid, the nature of human affairs can scarce admit of a remedy. But the mean rapacity, the monopolizing spirit of merchants and manufacturers, who neither are, nor ought to be, the rulers of mankind, though it cannot perhaps be corrected may very easily be prevented from disturbing the tranquillity of anybody but themselves (IV.3.38).

Indeed, controlling this dangerous aspect of capitalism has always been a core political project, and a central theoretical topic in ethics and theology. Most recently, a long political struggle to domesticate capitalism without smothering its positive potential culminated in the postwar 'golden age' when anti-trust legislation, regulatory agencies, civil rights, social insurance, unions, and the rest seemed to have contained its worst excesses. So Sandel gets something right when he identifies a change in the character of capitalism from the Reagan era onwards as those constraints were dismantled or allowed to decay. 
But I think Sandel is wrong about the source of this kind of corruption. Our institutions have not been corrupted by subtle changes in meaning brought about by dollar signs, but by an out of control beast that feeds off money.

I agree with Sandel that we need to tame capitalism again, so that it works for us rather than tries to eat us, and that this is a political rather than an academic project-about democratic deliberation over the public interest and the functioning of our social institutions, and the marshalling of popular opinion into electoral outcomes and political change. But I disagree with Sandel that this political project should be concerned with determining the 'true meaning' of things like baseball. Rather, it seems to me that what is required is a new social compact for the 21 st century that will channel the benefits of commercial society to all in a fair way and protect all of us, but especially the most vulnerable, from its excesses and depredations.

\section{REFERENCES}

Anderson, Elizabeth. 1993. Value in ethics and economics. Cambridge (MA): Harvard University Press.

Coase, Ronald H. 1937. The nature of the firm. Economica, 4 (16): 386-405.

Grant, Ruth W. 2012. Strings attached: untangling the ethics of incentives. Princeton: Princeton University Press.

Herzog, Lisa. 2013. Markets. In The Stanford Encyclopedia of Philosophy, edited by Edward N. Zalta. http://plato.stanford.edu/archives/fall2013/entries/markets/

Klein, Naomi. 1999. No logo: taking aim at the brand bullies. New York: St. Martins Press.

Lethem, Jonathan. 2014. Pending vegan. The New Yorker, April 7, 2014.

Polanyi, Karl. 1944. The great transformation: the political and economic origins of our time. Beacon Press.

Radin, Margaret Jane. 1996. Contested commodities. Cambridge (MA): Harvard University Press.

Rawls, John. 2005. Political liberalism [expanded edition]. New York: Columbia University Press.

Satz, Debra. 2010. Why some things should not be for sale: the moral limits of markets. Oxford: Oxford University Press.

Sen, Amartya. 1990. Gender and cooperative conflicts. In Persistent inequalities: women and world development, ed. Irene Tinker. Oxford: Oxford University Press, 123-149.

Titmuss, Richard M. 1970. The gift relationship: from human blood to social policy. New York: Pantheon Books.

Walzer, Michael. 1983. Spheres of justice: a defense of pluralism and equality. New York: Basic Books.

Zelizer, Viviana A. 2009. The purchase of intimacy. Princeton: Princeton University Press. 
Thomas R. Wells is an independent post-doctoral researcher affiliated with the Erasmus Institute for Philosophy and Economics (EIPE) at Erasmus University Rotterdam; and an editor of the Erasmus Journal for Philosophy and Economics. His research interests include human development, economics, ethics, and political philosophy.

Website: <www.twells.org >

Contact e-mail: <t.r.wells@dunelm.org.uk> 